\title{
Myśleć, budować, pamiętać - kreacje architektoniczne i krajobrazowe ,ku pamięci”. Studium przypadku restrukturyzacji terenów dawnego arsenału królewskiego w Londynie
}

\author{
Renata Jóźwik \\ Katedra Projektowania i Konserwacji Krajobrazu, Wydziat Ogrodnictwa i Architektury Krajobrazu, \\ Uniwersytet Przyrodniczyw Lublinie, e-mail: renata.jozwik@gmail.com
}

Streszczenie: W artykule naświetlono, jak obecnie ujmuje się pod względem architektonicznym i krajobrazowym kwestie związane z przeszłością, a w szczególności, jakie znaczenie ma autentyzm obiektu lub miejsca, kontekst oraz jak wpływa na kształtowanie architektoniczne opisane przez Lva Manovicha „poszerzanie rzeczywistości”. W niniejszym tekście nawiązano do wybranych koncepcji socjologicznych: Manovicha, Goffmana, Nory, Baumana, zwracając tym samym uwagę na rozproszenie przedmiotowego zagadnienia na inne dziedziny nauki. Na podstawie przedstawionego paradygmatu przestrzeni scenograficznej przeprowadzono studium restrukturyzacji terenów dawnego, królewskiego arsenału w Woolwich, w Londynie, który obrazuje współczesne problemy ochrony dziedzictwa.

Słowa kluczowe: ochrona dziedzictwa, królewski arsenał w Londynie, restrukturyzacja urbanistyczna.

\section{Wstęp}

Tytuł referatu nawiązuje do tekstu Martina Heideggera „Budować, myśleć, mieszkać” z 1952 r., w którym autor łączy zamieszkiwanie z budowaniem, ale nie w sensie technicznym, lecz przynależności do samego procesu [1]. W podobnej relacji obecnie można rozpatrywać kwestie związane z pamięcią, stąd niniejsze nawiązanie.

Temat przeszłości jest w ostatnich dekadach bardzo często podejmowany poprzez realizacje architektoniczne i krajobrazowe - w różnych formach. Niemal od początku, od kiedy przeszłość pojawiła się w świadomości jako wartość warta ochrony (XIX w.), jej koncepcja ewoluowała, a w ostatnich dekadach zmieniła się całkowicie postawa wobec obiektów już istniejących, mających znaczenie w perspektywie czasowej oraz elementów przeszłości nie mających bezpośredniego odniesienia materialnego - upamiętnia się wydarzenia, postaci itd. Fenomen przeszłości, a przede wszystkim różnorodność elementów z nią związanych, doprowadziły do rozszerzenia pojęciowego i ujmowania wszelkich kwestii jako „dziedzictwo", to z kolei powoduje często zatarcie różnic, jakie występują choćby pomiędzy: kwestią historii, a kwestią pamięci; obiektem historycznym, a miejscem wartym upamiętnienia itd. Istnieje potrzeba usystematyzowania i zdefiniowania pojęć, które pozwolą na rozróżnienie, w jaki sposób postępować z poszczególnymi obiektami ze względu na ich znaczenie dla dziedzictwa. 


\section{Ochrona, konserwacja, dziedzictwo}

Greogory Ashworth wskazuje na zmianę podejścia z całkowitej, bezwzględnej ochrony obiektu, takiej która nie przewiduje działań rozwojowych, w kierunku wykorzystania jego potencjału historycznego i znaczenia - ale niekoniecznie w sensie materialnym [2]. Związane jest to z powolnym odchodzeniem od wagi autentyzmu w kierunku interpretowania miejsc, czy obiektów; dostrzegania ich narracyjności i związanych z nimi historii - tworzenia tzw. nastroju. Taka zmiana jest kwestią sporów w dyskusjach akademickich, w których kwestionuje się taką wartość ochrony i wskazuje na niebezpieczeństwo zafałszowania historii. Sam Ashworth pisze: „dziedzictwo może być postrzegane jako proces, w którym przedmioty, wydarzenia, miejsca, działania, i postacie wywodzące się z przeszłości są przekształcone w doświadczenia przeżywane tu i teraz" [3], co może być pokusą do nazbyt barwnego przedstawiania historii, a w świetle przedstawionych w dalszej części referatu tendencji do teatralizacji przestrzeni, wręcz formą jej fabularyzowania.

\section{Teatralizacja przestrzeni}

Źródeł przemian, które dokonują się w obszarze problematyki konserwatorskiej, należy upatrywać m.in. w zmianie podejścia do przestrzeni. Rozwój kultury wizualnej - kinematografii, czy wirtualnej rzeczywistości początkowo osłabiły relacje społeczne, wagę przestrzeni rzeczywistej, postrzeganie świata - przede wszystkim stosunek człowieka do miejsc rzeczywistych. Pisał o tym Joshua Meyrowitz w 1985 r., minorowo wieszcząc kres przestrzeni [4]. Przestrzeń iluzyjna, obecna niegdyś tylko w ograniczonym zakresie, np. w przekaźnikach komputerowych, wnika do rzeczywistości, stając się swoistą hybrydą. Lev Manovich identyfikuje tzw. przestrzeń powiększona, definiując następująco: jest to „fizyczna przestrzeń, na którą nakłada się dynamicznie zmienna informacja" [5]. Te informacje dostarczane są przez aplikacje komórkowe, medialne ekrany, interaktywne informacje, opisy audialne, hologramy, projekcje - wszystko to, co w sposób multisensoryczny pozwala nam doświadczać miejsca, tylko że są to narracje (a w języku cyberkultury: dane), których prawdziwości nie sposób obiektywnie ocenić, zweryfikować.

Właśnie z potrzeby kreacji przestrzeni narracyjnej współcześnie przekształca się ją w kierunku tworzenia miejsc o walorach scenograficznych. W badaniach dotyczących przestrzeni od lat 70. XX w. odnotować należy także zmianę podejścia w naukach humanistycznych - polegający na tzw. zwrocie przestrzennym (ang. spatial turn), zgodnie z którym przestrzeń nie jest faktem obiektywnym, lecz społecznym. I tu pojawia się pierwsza wątpliwość, co konstytuuje prawdziwą przestrzeń? Miejsce (topos)? Czy warunki społeczne? Niewątpliwie miejsca, krajobraz, architektura są poddawane nieustannej interpretacji, zmianom zgodnym ze społecznymi oczekiwaniami. Według koncepcji dramaturgicznej Ervinga Goffmana [6] współczesny człowiek realizuje potrzebę ciągłej autoprezentacji, poprzez którą kreuje taki obraz siebie, jaki uznaje za właściwy. Dotyczy to także jego otoczenia i atrybutów, bowiem dopełniają one tenże obraz. Zatem przestrzeń publiczna staje się rodzajem teatru. Nie bez znaczenia przejawia się tutaj aspekt wizualności, zewnętrzności, a może także powierzchowności, jeśli ta kreacja jest niezgodna z prawdziwą tożsamością, bowiem właśnie z takiej potrzeby autoprezentacji jednostki, ale i w konsekwencji szerszych zbiorowości: grup społecznych, czy nawet całych narodów, z potrzeby manifestowania swoich poglądów poprzez identyfikowanie się z historią, tradycją, pamięcią o swoich korzeniach, niekiedy przeszłości 
traktowanej wybiórczo, upowszechniła się kwestia szerokiego ujmowania pamięci - przede wszystkim uzewnętrzniana jej w różny sposób. Natomiast z chęci ujęcia jak najpełniejszego dorobku historii, kultury, dokumentowania jej poprzez współczesne techniki wyłoniła się kwestia dziedzictwa. Pierre Nora już w latach 70. XX w. uczynił przedmiotem badań naukowych „miejsca pamięci”, przy czym w swoich pracach wyraźnie oddziela pamięć od historii, wskazując na narracyjny, ekspresyjny, a więc i subiektywny charakter pamięci i na obiektywny, faktograficzny charakter historii [7].

Ten aspekt jest niezwykle interesujący, jeśli się przełoży go na kreowanie przestrzeni, która z założenia ma mieć odniesienie do przeszłości, której to z kolei postawiono misję jednoczenia zbiorowości, a więc z natury rzeczy jest ona wówczas kompromisowa, niepełna i czasem niestety powierzchowna, bo bazuje na emocjach. Popularyzacja takiego podejścia, które nazwać można „teatralizacją przeszłości”, ale nie w wymiarze wydarzenia, tylko kreacji scenograficznej, zdominowała profesjonalną ochronę konserwatorską, zgodnej z zapisami Karty Weneckiej (1964) [8]. Budowanie historyzujących makiet stało się narzędziem do rozwoju turystyki kulturowej. Ta wyjątkowo mocna koncentracja na sprawach przeszłości spowolniła XX-wieczny proces modernizacji i wprowadza w świat opisany przez Zygmunta Baumana w jego ostatniej książce jako „retrotopia” [9].

\section{Duch przeszlości - dematerializacja i rematerializacja przeszlości w planowaniu przestrzennym i architekturze}

Przeniesienie idei, iż rzeczy mają swojego ducha, także miejsca (łac. genius loci), pozwoliło na rozwiniecie się nurtu badawczego nad narracyjnością przestrzeni i ukonstytuowało w nauce humanistyczne powiązania $\mathrm{z}$ architekturą. W kontekście przeprowadzanych w ostatnich dekadach licznych rewitalizacji w miejscach historycznych, obecnie kładzie się jest nacisk na przywrócenie życia (łac. re-vita), a za czynnik „,reanimujący” miejsce i stanowiący walor, sprzyjający temu, uznaje się przeszłość miejsca - jego materialne i niematerialne dziedzictwo. W budowaniu dramaturgii jednym z elementów kreacji jest architektura. To wykorzystanie ducha, nastroju można jednak uznać za namiastkę doświadczenia historycznego W porównaniu do możliwości styku z autentykiem. Problem ten rozwinął się i ujawnił w deklaracji ICOMOS z Xi'an w 2005 r. [10], kiedy do dyskursu nad ochroną dziedzictwa włączono odmienne podejście kultur wschodnich i zalecono szerokie interdyscyplinarne badania. „Przeżycie historyczne” stało się motywem przewodnim do kreacji, ekspresji architektonicznych - przede wszystkim do podtrzymywania historycznego krajobrazu miejskiego, który wobec dynamicznych przemian kulturowo-cywilizacyjny narażony jest na zatarcie, zniekształcenie, a w konsekwencji unicestwienie. Ta przesłanka oraz inne czynniki (m.in. ekonomiczne) stały się podstawą do sformułowania w 2011 r. nowych Rekomendacji w sprawie Historycznego Krajobrazu Miejskiego (UNESCO) [11], w którym to dokumencie, w punkcie 11., można przeczytać: „podejście krajobrazowe do historycznego dziedzictwa miejskiego ma na celu zachowanie jakości środowiska człowieka, poprzez wykorzystanie przestrzeni miejskiej w sposób efektywny (...)".

W nawiązaniu do przedstawionych koncepcji oraz studium współczesnej restrukturalizacji zespołu historycznego dawnego, królewskiego arsenału w Londynie podjęto próbę odpowiedzi na pytanie, co jest w architekturze nośnikiem pamięci? Czy nowa forma scenerii architektonicznej opowiadającej historię, która zastępuje dawne miejsce, może być wyrazem pamięci o przeszłości i czy oddaje tożsamość miejsca? 


\section{Tereny dawnego królewskiego arsenału w Londynie}

Tereny Królewskiego Arsenału w Woolwich, w Londynie (Royal Arsenal) są przykładem współczesnej restrukturyzacji terenu o znaczeniu historycznym, który pokazuje problematykę i stosowane narzędzia w procesie przekształcania obszaru ważnego pod względem dziedzictwa przemysłowo-militarnego, objętego ochroną konserwatorską, jako obszar, podobnie poszczególne budynki (budynki: klasy I, klasy II* i klasy II - klasyfikacja zgodna z zasadami ochrony zabytków właściwych dla Wielkiej Brytanii). Są także kapitalnym przykładem obrazującym, w jaki sposób obecnie dostosowuje się przestrzeń historyczną do współczesnych uwarunkowań, stosując przy tym koncepcję poszerzonej rzeczywistości.

\subsection{Historia i znaczenie miejsca}

W okresie panowania dynastii Tudorów na omawianych, ówcześnie podmiejskich terenach Woolwich znajdowała się stocznia królewska. W 1545 r. powstał dwór Tower Place. Według zapisów archiwalnych, w latach 40. XVII w. na terenach Warren (dawna nazwa) testowano broń. W $1671 \mathrm{r}$. tereny te stały się własnością królewską i zostały przeznaczone do magazynowania broni. Właściwy rozwój tego obszaru przypadł na przełom XVII i XVIII w.,

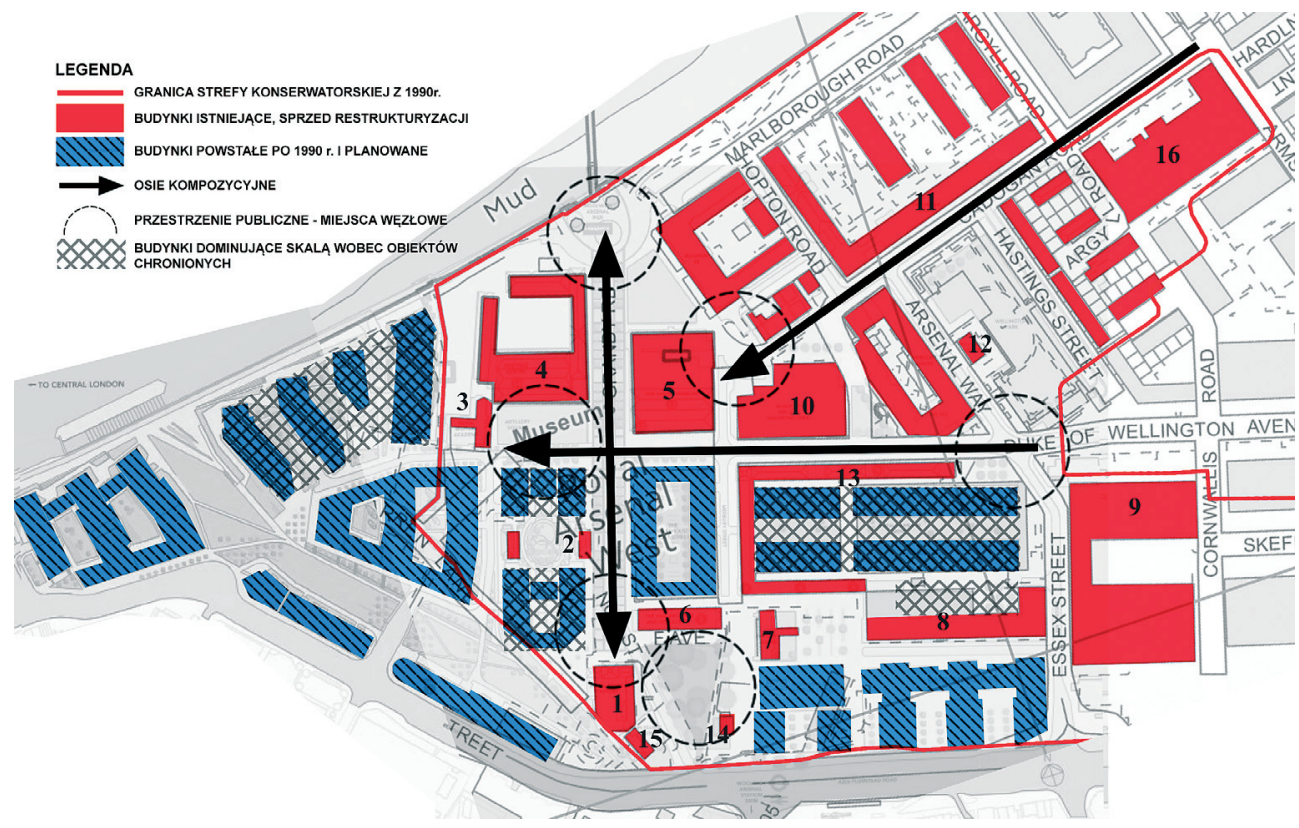

Ryc. 1. Plan terenu restrukturyzacji dawnego arsenału królewskiego w Londynie. Na rysunku widoczne są następujące obiekty: 1. Odlewnia mosiądzu (Royal Brass Foundry); 2. Pawilony laboratorium (Royal Laboratory, West \& East Pavilions); 3. Gmach akademii wojskowej (Royal Academy Military); 4. Obecne Heritage Center; 5. Muzeum artylerii (Firepower - The Royal Artillery Museum); 6. Dial Square Entrance Range; 7. Dom oficerów, 8. „Budynek 10” (Royal Carriage Factory); 9. Budynek strzelniczy (Gunnery House); 10. Montażownia broni (The Gun Mounting Shed); 11. The Grand Store; 12. Budynek odlewni (Foundry House); 13. Royal Carriage Mews; 14. Verbuggens House; 15. Dom wartownika; 16. Budynek z armatami (Cannon House). (opracowanie własne 2017 r.; na podstawie planu zagospodarowania oraz załącznika z granicą strefy konserwatorskiej z 1990 r.) 
kiedy to z Greenwich został przeniesiony budynek laboratorium. Wówczas, w 1696 r. rozpoczęła się oficjalna produkcja broni i amunicji. W latach 1715-17 powstała odlewnia mosiądzu (Royal Brass Foundry), jeden z kluczowych obiektów. Dzięki temu w tym czasie rozszerzono produkcję o wozy strzelnicze. W 1716 r. wybudowano koszary Królewskiego Pułku Artylerii (Royal Regiment of Artillery), zaś w 1719 r. Królewskiej Akademii Wojskowej (Royal Military Academy). Od 1805 r. na wniosek króla Jerzego III zakłady przyjęły nazwę „Royal Arsenal”. W okresie I wojny światowej cały zespół zajmował powierzchnię blisko 520 ha, zakłady zatrudniały około 80 tys. pracowników. Fabryka zamknęła produkcję w 1967 r. Do 1994 r. teren należał do Ministerstwa Obrony i do tego czasu blisko 22 budynki nie były użytkowane.

Obszar Royal Arsenal w całym okresie funkcjonowania ulegał przekształceniom, co było związane zarówno ze zmianami: w technikach obronnych, procesu produkcji broni, jak i ze zmianami w organizacji zakładu. Utrwaliły się pewne elementy układu, który ma cechy świadomie kształtowanej kompozycji. Tworzą one potencjał dla dalszego przekształcania jest to układ trzech osi, jasno określone granice, strefa wejściowa, poszerzenia, stanowiące obecnie place - przestrzeń publiczną [Ryc. 1.]. Układ zabudowy i szlaki komunikacji podporządkowane były dawniej funkcji terenu.

\subsection{Przekształcenia zespołu, uwarunkowania formalno-prawne}

Po przekazaniu przez Ministerstwo Obrony w 1994 r. obszaru jednostce rządowej English Partnership za symbolicznego funta podjęto decyzję o przeznaczeniu tego terenu na cele mieszkaniowe. W tym celu Ministerstwo Skarbu przeznaczyło 43 miliony funtów na odkażanie terenu i zabezpieczenie budowli, które długo stały nieużytkowane. W latach 1999-2008 przeprowadzano systematyczne badania archeologiczne (1999-2008 - Oxford Archeology; 2003-2005 Pre-Construct Archeology). Teren o powierzchni 30 ha w $2001 \mathrm{r}$. zakupiła firma Berkley Homes i wówczas sporządzono plan zagospodarowania tego terenu, który zakładał podział na części: funkcje mieszane, cele kulturalne, mieszkaniowe i przemysłowe. Plan był aktualizowany w latach 2006, 2011, 2013, głównie z powodu inwestycji kolejowej. Ostatecznie proces rewitalizacji zaplanowano na 30 lat, w ciągu których ma powstać ok. 5000 nowych mieszkań (komercyjnych i dostępnych), usługi i handel, obiekty kultury, przestrzeń publiczna, w tym tereny zieleni urządzonej, linia kolejowa Crossrail wraz ze stacją Woolwich Arsenal.

W 1990 r. została wyznaczona strefa ochrony konserwatorskiej [12], jednak nie ustalono żadnych szczegółowych zasad ochrony dla tego obszaru. Pod ochroną znajdują się także poszczególne budynki - m.in.: Verbruggens House (obiekt klasy II), Main Guradroom - główna wartownia (obiekt klasy II), Brass Foundry - odlewnia mosiądzu (obiekt klasy I), Royal Laboratory, West \& East Pavilion - laboratorium (obiekt klasy II), budynek 10 - Royal Carriage Factory - fabryka wozów (obiekt klasy II), budynek 11 - Officers House - dom oficerów (obiekt klasy II), budynek 19 (obiekt klasy II), Dial Square Entrance Range (obiekt klasy II*), budynek wejściowy w obszar Royal Arsenal (obiekt klasy II). Wzajemne relacje przestrzenne wyżej wymienionych obiektów składają się na wartość całego obszaru jako zespołu.

W dokumencie National Planning Policy Framework (NPPF) z 2012 r. [13] określono, jak oceniać wartość obiektu pod względem znaczenia kulturowego. Według NPPF jest to obiekt, który ma wartość dla pokolenia obecnego i przyszłych ze względu na interes dziedzictwa: archeologiczny, architektoniczny, artystyczny, estetyczny. W wytycznych Planning for the Historic Environment - Practice Guide z 2010 r. [14] wartość dziedzictwa jest sumą wartości architektonicznych, historycznych, artystycznych i archeologicznych. Nieco inaczej 
ujmuje tę kwestię dokument Conservation Priciples, Policies and Guidance z 2008 r. [15], w którym wylistowane są następujące wartości, które mogą wystąpić w danym miejscu: dowodowe, historyczne, estetyczne i wspólnotowe. Wartość historyczna jest tutaj także opisana jako posiadająca ,walor ilustracyjny i asocjacyjny”.

Ochrona niniejszego zespołu jest na pewno w interesie historycznym. Arsenał jako całość przedstawia wartość historyczną i stanowi wartość dowodową. Znaczenie kompleksu Royal Arsenal zostało dostrzeżone już w końcu XIX w., kiedy to arsenał opisywano jako jeden z największych na świecie - dlatego jest unikatowym obiektem jako całość. Konkretne budynki są materialnym świadectwem faktu istnienia arsenału, ale jednocześnie pokazują aspekty związane z przemysłem, procesem i organizacją produkcji. Brakujące elementy wyposażenia $\mathrm{w}$ niektórych obiektach uzupełniono poprzez oryginalne eksponaty i opisy i umieszczono w specjalnym obiekcie, którego celem jest dokumentacja dziedzictwa tego miejsca - Heritage Centre and Firepower - The Royal Artillery Museum. W tym przypadku występuje aspekt poszerzenia rzeczywistości o elementy informacji i narracji. Budynki często zmieniały się w związku ze zmianą funkcji, bądź zmianą procesu produkcji. Według dokumentu Conservation Principle budynki są dowodem przeszłej działalności człowieka [16]. Poprzez ich wygląd, układ przekazywane są informacje o przeszłości - o osiągnięciach grup inżynierskich mających znaczenie dla historii techniki. Skupienie dużej liczby budynków o historycznym znaczeniu i specyficznym charakterze tworzy nastrój i etos miejsca. Autentyzm tych obiektów jest niezmiernie istotny.

W całej strefie występują wartości architektoniczne, artystyczne i estetyczne. Przywoływany dokument Conservation Principles wyznacza czynniki, które je określają tj.: forma, proporcje, skala, masa (wizualna), kształt, sylweta, widok, perspektywa, powiązania oraz materiały, występująca roślinność, sposób dekoracji, detale i elementy rękodzieła. Wartość estetyczną może stanowić odpowiednie zestawienie dawnej zabudowy z nowymi obiektami [17]. W przypadku Royal Arsenal są to często specyficzne obiekty charakteryzujące się dużą powierzchnią użytkową, o elewacjach z tzw. ślepymi oknami - są to cechy wynikające $\mathrm{z}$ dawnego użytkowania przemysłowego.

Lista obiektów i obszarów chronionych z 1990 r. [18] odnosi się do procedur związanych z pozyskaniem pozwolenia na budowę dla obiektów chronionych. Rozdział 66. mówi, iż to od decydentów wymaga się specjalnego zachowania budynku lub jego otoczenia, uwzględnienia cech o szczególnym znaczeniu architektonicznym lub historycznym. Na podstawie rozdziału 72. Należy zwrócić szczególną uwagę na zachowanie bądź wzmocnienie charakteru lub wyglądu danego miejsca, co poniekąd ukierunkowuje działania także na kontekst.

Paragraf 128. National Planning Policy Framework [19] mówi o tym, że podczas składania wniosku właściwy urząd ma obowiązek wymagać od wnioskodawcy opisu planowanych zmian i opisu ich znaczenia na wartość chronioną obiektu, zaś poziom szczegółowości nie może tylko ograniczyć się do zrozumienia znaczenia potencjalnych zmian. Ocena tego dokumentu leży po stronie władz, które mają obowiązek rzetelnego i profesjonalnego sprawdzenia ustaleń. Chroni to przed sytuacjami konfliktowymi, jakie mogłyby ewentualnie wystąpić podczas realizacji inwestycji. Zgodnie z paragrafem 131. podczas aplikowania wniosku należy wziąć pod uwagę: potrzebę podtrzymywania i wzmacniania znaczenia obiektu dla dziedzictwa kulturowego oraz wprowadzenie żywotnych funkcji zgodnych z intencją ochrony; pozytywny wkład w aspekty ochrony oraz ich wpływ na sprawy gospodarczo-społeczne; pozytywne elementy gwarantujące nowy rozwój, wkład w lokalny charakter i unikatowość miejsca [20]. Według paragrafu 133. dobry projekt zapewnia atrakcyjne, użyteczne i trwałe oraz dostosowane do miejsca rozwiązania i jest kluczowym elementem trwałego rozwoju. Władze mogą odmówić zgody na proponowane zmiany, chyba że wnioskodawca wykaże, 
że: natura zasobu uniemożliwia jakiekolwiek inne zagospodarowanie; uwarunkuje to ekonomicznie - straty przewyższą korzyści; nie możliwe jest pozyskanie funduszy publicznych/ charytatywnych na odnowę [21]. Zgodnie z paragrafem 137 należy tak prowadzić działania, aby ujawnić znaczenie dziedzictwa danego obiektu, poszukiwać dla nich nowych form rozwojowych, które będą respektować wartości chronione [22].

Plan Local Plan dla gminy Royal Borough of Greenwich z lipca 2014 r. w rozdziale 4.4 Projektowanie i dziedzictwo (oryg. Design and heritage) [23] wskazuje, że nowe zmiany muszą przynieść wysoką jakość przestrzenną, poprawiać środowisko kulturowe i naturalne, być spójne z kontekstem. Jako istotne wymienia się następujące aspekty: topografia, krajobraz, krawędzie, czynniki naturalne, zabudowa, punkty orientacyjne, widoki i panoramy, architektura, drzewa, jakość i dobór materiałów, ustalony układ i charakter przestrzenny, skala, wysokość, sąsiedztwo, czynniki: architektoniczne, historyczne, archeologiczne, efektywne wykorzystanie gruntów, potencjał mieszania funkcji, wzorce przemieszczania się (szczególnie w ruchu pieszym i rowerowym), różnorodność kulturowa, izolacja od hałasu. To władze lokalne zobowiązują się do ochrony i wzmacniania charakteru i wyglądu obszarów chronionych.

\section{Podsumowanie}

Obecne zagospodarowanie terenów dawnego arsenału królewskiego w Londynie można uznać za zgodne ze zrównoważonym rozwojem, bowiem realizowane są cele publiczne (obiekty kultury, transportu publicznego), a także pilne potrzeby wynikające z niedoboru mieszkaniowego. W zakresie ochrony środowiska dokonano niezbędnych czynności proekologicznych, uzupełniono układ o tereny zieleni (np. Wellington Park).

W zakresie ochrony dziedzictwa cały obszar zawiera elementy związane z dawnym zagospodarowaniem. Zachowano główny układ urbanistyczny. Pozostawiono fizycznie budynki dawnego arsenału i zaadaptowano je do nowych celów - np.: budynek Royal Military Academy na luksusowe apartamenty, fabrykę uzbrojenia przy placu artyleryjskim na centrum promujące dziedzictwo (Greenwich Heritage Centre), powstało muzeum artylerii (Firepower - The Royal Artillery Museum) - te budynki w 2017 r. zakupiła gmina i planuje rozszerzyć funkcje kulturalne o teatr i inne pomieszczenia - w budynku Dial Arch Square powstał lokalny pub itd. Jednakże włączenie nowych elementów architektonicznych, także tych o skali dominującej, w strukturę historyczną zespołu arsenału, powoduje fragmentację całości.

Elementem historycznej scenerii jest oś pomiędzy odlewnią mosiądzu a nadbrzeżem Tamizy, gdzie usytuowano rzeźbę miejską w postaci stalowych postaci nawiązującą do przeszłości pt. „Assembly” (co znaczy „,zgromadzenie”), autorstwa Petera Burke’a. Fot. 1. Jako kontrowersyjne można uznać naruszenie skali zabudowy chronionej, poprzez lokalizowanie znacznie przewyższających budynków w bardzo bliskim sąsiedztwie - i tak przykładowo: budynki laboratorium (West \& East Royal Pavilion Laboratory) 2-kondygnacyjne ze stromym spadzistym dachem będą otoczone 7-kondygnacyjnymi blokami mieszkalnymi. Fot. 2., również za budynkiem fabryki wozów Royal Carriage Factory pobudowano tak samo wysokie budynki mieszkaniowe. To powoduje, iż nie do końca można „doświadczać” miejsca historycznego. Jakkolwiek o przeszłości przypomina wiele elementów wyposażenia przestrzeni publicznej, która kształtowana jest w sposób scenograficzny, są one wyrazem pamięci, dziedzictwa, ale ich wartość historyczna niknie wraz ze zmianą kontekstu przestrzennego. Można z całą pewnością mówić o „poszerzonej przestrzeni”, włączaniu elementów pamięci do miejsca poprzez zastosowanie nowych technik medialnych (liczne publikacje, strony WWW, interaktywne ekspozycje). Ta część historii miejsca została skoncentrowana w specjalnych obiektach opowiadających o przeszłości, jednak obcowanie z autentyzmem miejsca 
nie jest czytelne poprzez wprowadzone zmiany w strukturze urbanistycznej. Fot. 3. Jest to zgodne z obecnymi tendencjami i liberalizacją postępowania wobec obiektów historycznych, czego dowodem są zapisy Rekomendacji UNESCO promujące kompromisowe rozwiązania. Znamienny jest także brak przez blisko 30 lat ustaleń konserwatorskich dla omawianego obszaru. Studium przypadku arsenału królewskiego w Londynie pokazuje wagę kontekstu dla ochrony historycznego zespołu oraz to, że czasami poprawne, lecz ogólne zapisy prawne nie gwarantują pełnej ochrony.



Fot. 1. Arsenał królewski w Londynie. Rzeźba na głównej osi urbanistycznej, autorstwa Petera Burke'a pt. Zgromadzenie. W tle widoczny budynek odlewni mosiądzu - najcenniejszy zabytek w zespole (Fot. Renata Jóźwik, 2015 r.)



Fot. 2. Arsenał królewski w Londynie. Strefa wejściowa. Na osi widoczny wschodni pawilon laboratorium. Na zdjęciu zaznaczono planowaną 7-kondygnacyjną zabudowę, która zdominuje kluczowy widok. (Fot. Renata Jóźwik, 2015 r.) 


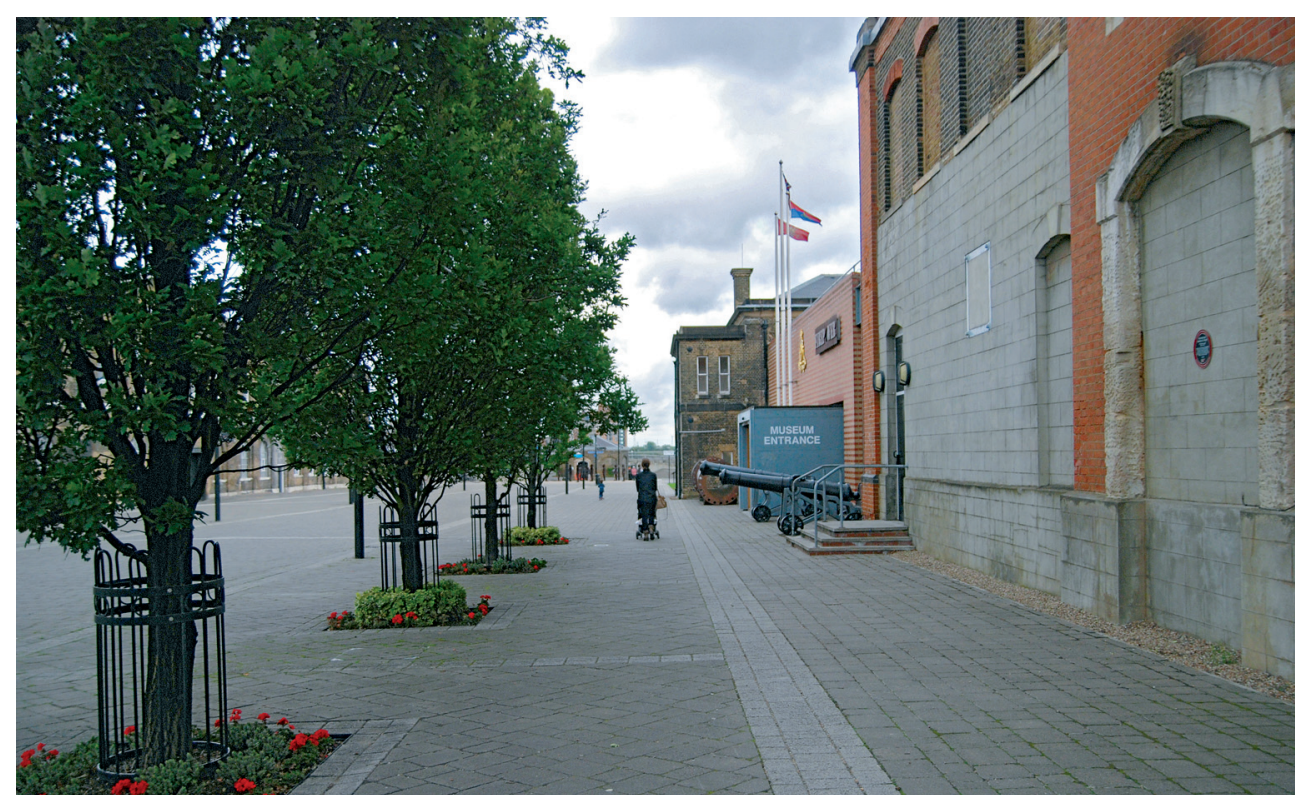

Fot. 3. Arsenał królewski w Londynie. Wejście do Muzeum Artylerii. Widoczne na zdjęciu licznie występujące na terenie arsenału obiekty strzelnicze. (Fot. Renata Jóźwik, 2015 r.)

\section{Literatura:}

[1] Heidegger M. Myśleć, mieszkać, budować. tłum. Michalski K., [w:] Teksty: teoria literatury, krytyka, interpretacja 6 (18) (1974) 137-152.

[2] Ashworth G. Planowanie dziedzictwa. Międzynarodowe Centrum Kultury, Kraków 2015, s. 7.

[3] tamże, s. 22.

[4] Meyrowitz J. No sense of place. The impact of electronic media on social behaviour. Oxford University Press, New York 1985.

[5] Manovich L. Poetyka powiększonej przestrzeni. [w:] Miasto w sztuce - sztuka miasta, Rewers E. (red.), Universitas, Kraków 2010, s. 597.

[6] Goffman E. Człowiek w teatrze życia codziennego. [w:] Antropologia widowisk. Zagadnienia i wybór tekstów, Mencwel A. (red.), Wydawnictwa Uniwersytetu Warszawskiego, Warszawa 2005.

[7] Nora P. Czas pamięci. tłum. Dłuski W., Res Publica Nowa 7 (2001) 37-43.

[8] The Venice Charter / La Charte de Venise 1964-1994. ICOMOS 1994.

[9] Bauman Z. Retrotopia. John Wiley \& Sons, Inc. 2017.

[10] Xi'an Declarationon the conservation of the setting of heritage structures, sites and areas. ICOMOS 2005.

[11] Recommendation on the historic urban landscape. UNESCO 2011.

[12] Royal Arsenal conservation area map boundaries. Environmental and Planning. Royal Borough of Greenwich, plik PDF, http://www.royalgreenwich.gov.uk/downloads/download/656/royal_arsenal_conservation_area_map, dostęp: 24.06.2017.

[13] National Planning Policy Framework (NPPF). Department for Communities and Local Government, Crown Copywrite 2012, s. 56.

[14] PPS5 Planning for the Historic Environment: Historic Environment Planning Practice Guide. Historic England (English Heritage). Department for Communities and Local Government, Crown Copywrite 2010, s. 8. 
[15] Conservation Principles, Policies and Guidance for the sustainable management of the historic environment. Historic England (English Heritage), 2008, s. 7, 27-32.

[16] Tamże, s. 7, 27-32.

[17] Tamże, s. 30.

[18] Planning (Listed Buildings and Conservation Areas) Act 1990. Chapter 9. Parlament Wielkiej Brytanii, Crown Copywrite 1990, s. 41.

[19] Dz. cyt., National Planning..., s. 30.

[20] Tamże, s. 31.

[21] Tamże, s. 31.

[22] Tamże, s. 32.

[23] Royal Greenwich Local Plan: Core Strategy with Detailed Policies. Royal Borough of Greenwich. 2014, s. 91.

\title{
Thinking, building, remember - architectural and landscape creations "in remembrance". Case study of the Royal Arsenal in Woolwich, London
}

\section{Renata Jóźwik}

The Department of Landscape Design and Conservation at the Faculty of Horticulture and Landscape Architecture, University of Life Science in Lublin, e-mail: renata.jozwik@gmail.com

\begin{abstract}
The article presents how architectural and landscape issues relate to the past, in particular the significance of an authenticity of an object or place, its context, and how „expanding reality” described by Lev Manovich influences the architectural design. In the article references to selected sociological concepts of Manovich, Goffman, Nora, Bauman, paying attention to the dispersion of the subject matter into other fields of science. Based on the paradigm presented in the scenography space, a study of the restructuring of the Royal Arsenal area in Woolwich, London, which illustrates the contemporary problems of heritage protection.
\end{abstract}

Keywords: heritage protection, The Royal Arsenal in London, urban restructuring. 